\title{
Pengaruh Permainan Sirkuit Pos Geometri Terhadap Motorik Kasar Anak Usia 5-6 Tahun
}

\author{
Juliana Sihite ${ }^{1 凶}$, Dimyati $^{2}$ \\ Pendidikan Anak Usia Dini, Universitas Negeri Yogyakarta, Indonesia(1) \\ Pendidikan Ilmu Keolahragaan, Universitas Negeri Yogyakarta, Indonesia(2) \\ DOI: $10.31004 /$ obsesi.v6i3.1896
}

\begin{abstract}
Abstrak
Keterampilan motorik kasar memberikan dampak positif bagi kehidupan anak jangka panjang. Permainan sirkuit pos geometri adalah kegiatan bermain yang dapat menstimulasi perkembangan motorik kasar anak, sehingga untuk melihat pengaruh permainan sirkuit pos geometri terhadap motorik kasar anak usia 5-6 tahun. Penelitian ini bertujuan untuk mengetahui pengaruh permainan sirkuit pos geometri terhadap motorik kasar anak usia 5-6 tahun. Metode yang digunakan dalam penelitian ini adalah quasi experiment dengan one group pretest-posttest design. Subjek penelitian melibatkan 20 orang anak. Teknik pengumpulan data dilakukan dengan cara observasi dan tes. Hasil penelitian ini menunjukan adanya pengaruh permainan sirkuit pos geometri terhadap motorik kasar anak usia 5-6 tahun. Hal ini dibuktikan oleh uji hipotesis nilai sig. (2-tailed) sebesar 0,000 yang artinya sig. < 0,05 maka, dapat disimpulkan bahwa terdapat pengaruh yang signifikan antar hasil pretest dan posttest. Hal tersebut memberikan implikasi bahwa permainan sirkuit pos geometri berpengaruh secara signifikan dalam menstimulasi motorik kasar anak.
\end{abstract}

Kata Kunci: anak usia dini; motorik kasar; permainan sirkuit pos geometri

\begin{abstract}
Gross motor skills have a positive impact on children's long-term lives. Geometry post circuit game is a play activity that can stimulate children's gross motor development, so to see the effect of geometry post circuit game on gross motor skills of children aged 5-6 years. This study aims to determine the effect of the geometric post circuit game on the gross motor skills of children aged 5-6 years. The method used in this study is a quasi-experimental with one group pretest-posttest design. The research subjects involved 20 children. Data collection techniques were carried out by means of observation and tests. The results of this study indicate the influence of the geometric post circuit game on the gross motor skills of children aged 5-6 years. This is evidenced by the hypothesis test of the value of sig. (2-tailed) of 0.000 which means sig. $<0.05$, it can be concluded that there is a significant effect between the results of the pretest and posttest. This implies that the post geometry circuit game has a significant effect on stimulating children's gross motor skills.
\end{abstract}

Keywords: early childhood; rough motoric; geometry post circuit game

Copyright (c) 2022 Juliana Sihite, Dimyati

$\triangle$ Corresponding author :

Email Address : julianasihite15@gmail.com(Yogyakarta, Indonesia)

Received 30 May 2022, Accepted 15 November 2021, Published 2 January 2022 


\section{PENDAHULUAN}

Kualitas masa depan seseorang dapat ditentukan oleh perkembangan dan pertumbuhan anak semasa usia dini. Pada masa ini, anak mulai peka dan sensitif terhadap macam rangsangan (Fadillah, 2012). Sehingga diharapkan pada masa ini dapat dijadikan masa untuk menumbuhkan, memupuk, mendorong,dan menyediakan lingkungan yang memungkinkan anak untuk mengenali dan mengembangkan potensi dalam diri anak seoptimal mungkin. Pemberian stimulasi dapat mengembangkan kemampuan dan potensi anak secara optimal, namun sebaliknya jika kemampuan dan potensi tersebut tidak dikembangkan dengan baik maka anak akan kehilangan momentum penting dalam hidupnya (Mutiah, 2012). Menurut Wahyudi \& Agustin(Ramdani \& Azizah, 2020) perkembangan fisik merupakan salah satu aspek yang cukup signifikan dalam perkembangan anak usia dini. Hal ini dikarenakan, perkembangan fisik motorik akan membangun fondasi untuk perkembangan lainnya seperti perkembangan kognitif, sosial, dan emosional mereka(Botha \& Africa, 2020; Lopes et al., 2013). Istilah motorik menggambarkan berbagai kompetensi fisik, termasuk pada keseimbangan dan stabilitas, gerakan terkoordinasi dan memanipulasi objek (Nasution \& Sutapa, 2021). Kompetensi keterampilan motorik (misalnya keterampilan motorik dasar seperti keseimbangan, melompat, melempar) merupakan bagian integral dari anak-anak secara fisik, sehingga mengurangi kemungkinan mengembangkan aktivitas fisik yang tidak sehat dan lintasan badan (Barnett et al., 2019; Teresa et al., 2016).

Masalah yang sering dikaitkan dengan motorik ialah status gizi pada anak.Status gizi yang kurang akan mengakibatkan anak mengalami keterlambatan dalam perkembangan dan pertumbuhannya, dimana menandakan ketidakseimbangan antara jumlah asupan gizi yang didapat dengan kebutuhan zat-zat gizi yang diterima oleh tubuh terutama otak, akibatnya menganggu pertumbuhan dan perkembangan anak (Hasdianah et al., 2014). Data Riset Kesehatan Dasar Indonesia tahun 2018 menunjukkan bahwa pada anak usia 5-12 tahun prevalensi sangat pendek sebanyak 6,7\%, prevalensi pendek 16,9\%, prevalensi sangat kurus 2,4\%, perevalensi kurus 6,8\%, gemuk 10,8\%, dan obesitas sebanyak 9,2\%(Republik Indonesia, n.d.). Anak yang menerima asupan gizi yang baik biasanya terlihat lebih aktif. Sedangkan anak yang menerima asupan gizi yang tidak sesuai dengan takarannya akan menyebabkan gangguan pada perkembangan anak terkhusus pada perkembangan motorik anak (Charles et al., 2021).

Dari pemaparan diatas, permasalahan yang disoroti dalam penelitian ini yang dapatmempengaruhi motorik kasar anakialah obesitas. Obesitas terjadi karena kurangnya melakukan pergerakan tubuh sehingga anak mengalami kenaikan berat badan.Salah satu penyebab obesitas pada anak ialah pemberian gadget bagi anak. Hal ini didukung oleh penelitianMorrison et al. (2018)yang mengemukakan bahwa akibat bermain gadget anak akan mengalami obesitas anak-anak mengalami kelebihan berat badan (obesitas) menunjukkan aktivitas fisik yang lebih rendah dengan anak yang memiliki berat badan normal. Sulistyaningtyas\& Fauziah (2019)juga memaparkan bahwa saat ini, dunia berada pada era perkembangan teknologi yang sangat pesat tidak terkecuali dengan Indonesia. Sejak balita anak sudah banyak terkontaminasi oleh gadget. Hasil riset Badan Pusat Statistik tahun 2020 menyebutkan bahwa sebanyak $29 \%$ anak usia dini di Indonesia menggunakan telepon seluler. Rinciannya, bayi yang berusia kurang dari satu tahun sebesar 3,5\%, anak balita 1-4 tahun sebesar 25,9\%, dan anak prasekekolah 5-6 tahun sebesar 47,7\%. Selain itu, sebanyak $12 \%$ anak pada usia ini mengakses internet. Anak prasekolah memiliki proporsi paling besar, yakni $20,1 \%$, dibandingkan balita yang sebesar $10,7 \%$ dan bayi $0,9 \%$. Sedangkan untuk penggunaan komputer hanya sebesar $0-1 \%$. Oleh karena permasalahan ini, diperlukan kegiatan yang memerlukan aktivitas gerak yang dapat melatih fisik anak. Salah satu aktivitas gerak yang sering dilakukan anak ialah kegiatan bermain. 
Bermain adalah hal yang mendasar bagi kebutuhan anak dan sangat penting untuk anak, dimana anak terlibat secara efektif dalam berbagai kegiatan dengan temantemannya atau kelompok, kegiatan bermain memberi peluang bagi anak untuk bereksplorasi, anak akan menemukan sesuatu yang bermanfaat bagi perkembangnnya(Shirin, 2020; Yus, 2013). Dalam situasi bermain anak dapat menunjukkan bakat, fantasi dan kecenderungannya. Anak menghayati berbagai kondisi emosi yang mungkin muncul seperti rasa senang, gembira, tegang, kepuasan dan mungkin rasa kecewa (Mutiah, 2012). Anak belajar melalui bermain dan bergerak dalam mengembangkan pemahaman lingkungan dan pengerahuan melalui aktivitas pancaindrawi(Montessori, 2019).Dampak yang harus tercipta dari kegiatan bermain ialah tumbuh dan berkembangnya potensi fisik-motorik, afektif, dan kognitif anak, yang artinya bermain bagi anak-anak tidak semata-mata tentang persoalan kegiatan yang menyenangkan saja, tetapi juga kegiatan yang menyenangkan juga harus mampu mengoptimalkan pertumbuhan dan perkembangan fisik-motorik yang sehat; potensi afektif, dan kognitif anak. Potensi fisik-motorik berkaitan dengan gerakan yang menumbuhkan fisik anak sehingga anak menjadi pribadi yang sehat (Kurniawan et al., 2020).Potensi fisik motorik dibagi menjadi dua yaitu motorik kasar dan motorik halus. Namun, pada penelitian ini peneliti berfokus pada motorik kasar.

Keterampilan motorik kasar didefinisikan sebagai aspek perkembangan yang berkaitan dengan kemampuan anak untuk bergerak yang melibatkan otot-otot besar seperti duduk, berdiri, berlari, dan melompat (Meylia et al., 2020). Usia 2-7 tahun merupakan usia fudamental, sehingga pada fase ini ada baiknya kemampuan motorik kasar anak distimulasi. Hal ini dilakukan karena motorik kasar memberi peranan yang sangat penting untuk menjalani hidup sepanjang hayat mereka(Mahmud, 2018).Keterampilan motorik kasar memberikan dampak positif seperti peningkatan kemampuan kognitif, kebugaran, kardiopernapasan yang lebih baik, persepsi diri yang lebih tinggi, peningkatan aktivitas fisik dan status berat badan (Veldman et al., 2019). Selain itu, Perkembangan motorik juga merupakan salah satu domain kunci dari pembelajaran awal dan perkembangan bersama dengan kognitif dan sosial-emosional untuk kesiapan sekolah dan berkontribusi pada keberhasilan akademik jangka panjang (In: Administration for Children and Families, 2015). Oleh karena itu,perkembangan motorik kasar sangat perlu untuk dikembangkan sejak usia dini. . Salah satu permainan yang dapat membantu meningkatkan motorik kasar anak usia 5-6 tahun ialah permainan sirkuit pos geometri.

Permainan sirkuit pos geometri merupakan permainan diadaptasi dari circuit training, sebuah istilah untuk melatih fisik motorik dan kebugaran dengan diberi nama Pos geometri. Circuit training adalah suatu metode latihan aerobic yang terdiri dari beberapa pos latihan, yaitu dari 8 sampai 16 pos latihan (Suharjana, 2014). Keseharian anak tidak terlepas dari bermain, maka latihan sirkuit ini dapat dimodifikasikan ke dalam permainan sirkuit pos geometri. Bentuk latihan sirkuit yang terdiri dari beberapa unsur fisik yang dapat dilatih. Rangkaian permainan sirkuit ini harus dapat mengembangkan gerakan pembentukan otot, baik menggunakan cakupan gerakan dasar lokomotor, non lokomotor maupun manipulatif. Latihan sirkuit adalahmetode latihan kebugaran yang dirancang dalam pola melingkar yang harus dilewati satu persatu untuk meningkatkan kebugaran jasmani seperti kekuatan, kelincahan, kelentukan, ketepatan dan keseimbangan (Susanti, 2014). Sehingga dapat dikatakan bahwa permainan sirkuit pos geometri adalah serangkaian permainan yang terdiri dari beberapa unsur motorik yang terdiri dari beberapa pos yang dilakukan secara berkesinambungan, dimana pada setiap posnya diberi gambar bentuk geometri. Permainan sirkuit pos geometri ini masuk dalam bermain pararel play (bermain paralel), yang artinya kegiatan ini dilakukan oleh anak dengan kegiatan yang sama namun tanpa adanya kerja sama antar anak. Kegiatan ini menciptakan suasana menyenangkan, menantang dan melatih kemandirian anak.

Berdasarkan observasi awal yang dilakukan peneliti pada bulan Januari 2021 di PAUD Mawar, Desa Simamora ditemukan bahwa terdapat anak yang memiliki keterampilan 
motorik khususnya motorik kasar yang masih tergolong rendah. Saat anak diminta untuk memindahkan bola dengan berlari bolak-balik, anak yang belum mampu untuk memindahkan bola dengan jarak 3 meter dalam waktu $<20$ detik. Selain itu, anak belum mampu bergerak lincah pada kegiatan berlari zig-zagdalam waktu $<20$ detik, anak juga belum mampu melompati hulahoop sambil mengubah posisi gelas plastik, anak belum mampu berjalan seimbang di papan titian sepanjang 3 meter tanpa terjatuh. Dari hasil wawancara dan observasi motorik kasar yang dilakukan di dapatkan bahwa pemberian stimulasi motorik kasar masih monoton dan membosankan sehingga anak merasa jenuh bila mengulang permainan itu. Selain itu, kegiatan bermain diluar ruangan kelas hanya dilakukan sekali seminggu. Dalam menstimulasi perkembangan motorik kasar guru biasanya mengajak anak untuk melompat ditempat, bermain permainan tradisional seperti gobak sodor, engklek, martarompah/bakiak dan senam pagi yang dilakukan sekali seminggu. Berdasarkan hal tersebut, maka guru perlu memberikan metode atau model pembelajaran berbasis permainan yang dapat meningkatkan kemampuan motorik kasar anak agar maksimal. Oleh karena itu, Peneliti tertarik untuk meneliti "pengaruh permainan sirkuit pos geometri terhadap motorik kasar anak usia 5-6 tahun".

\section{METODOLOGI}

Jenis penelitian yang digunakan pada penelitian ini adalah jenis penelitian kuantitatif yaitu quasi-experiment dengan desain one group pretest-posttest. Desain penelitian ini dilaksanakan pretest sebelum diberikan perlakuan dan posttest setelah diberikan perlakuan. Dengan demikian hasilnya diketahui lebih akurat, dikarenakan adanya perbandingan dari hasil sebelum dan sesudah diberi perlakuan (Sugiyono, 2019). Pelaksanaan penelitian dilakukan pada bulan Januari-Maret 2021 pada salah satu PAUD di Kecamatan Baktiraja. Subjek penelitian yang berpartisipasi sebanyak 20 orang anak yang berusia 5-6 tahun. Gambar 1, desain dari one group pretest.

$$
\mathrm{O}_{1} \mathrm{XO}_{2}
$$

\section{Gambar 1. Desain one group pretest-posttest}

Keterangan:

O1 = Hasil sebelum diberikan perlakuan

O2 = Hasil setelah diberikan perlakuan

Perlakuan yang diberikan kepada anak dalam penelitian ini ialah permainan sirkuit pos geometri, dimana pada pelaksanaannya diadakan diluar ruangan atau lapangan sekolah. Berdasarkan penelitian sebelunya anak kurang mendapatkan pengalaman bermain secara langsung di dalam ruangan. Pada Permainan ini ada 4 kegiatan modifikasi yang memuat aspek motorik kasar anak. Kegiatan bermain tersebut sebagai berikut berlari zig-zag, memindahkan bola dengan berlari bolak balik, berjalan jinjitpada papan titian, melompati hulahoop sambil mengubah posisi gelas plastik. Anak harus melewati setiap pos hingga garis finish kemudian akan disambung oleh pemain berikutnya.

Rangkaian Prosedur penelitian pada penelitian ini yaitu pre-test untuk mengetahui tingkat kemampuan motorik kasar anak usia 5-6 tahun sebelum diberikan perlakuan berupa permainan sirkuit pos geometri.Setelah itu, post-test anak diberikan perlakukan dengan menerapkan model permainan sirkuit pos geometri. Kegiatan permainan tersebut adalah (1) berlari zig-zag mengikuti pola dalam waktu <20 detik; (2) berlari bolakbalik sambil memindahkan bola sebanyak mungkin dengan jarak 3 meter; (3) berjalan jinjit pada papan titian dengan jarak 3 meter; (4) melompati 4 hulahoop sambil mengubah posisi gelas plastik. Setelah diberikan perlakukan pada anak maka dilakukan post-test untuk mengetahui pengaruh permainan sirkuit pos geometri terhadap kemampuan motorik 
kasar anak usia 5-6 tahun. Pre-test dan post-test dilakukan untuk mengetahui adakah pengaruh model permainan sirkuit pos geometri terhadap motorik kasar anak usia 5-6 tahun.

Teknik pengumpulan data pada penelitian ini menggunakan observasi dan test. Data yang didapatkan kemudian dianalisis secara kuantitatif untuk mengetahui perbandingan hasil perlakuan sebelum dan sesudahdiberikan kepada anak. Instrumen pengumpulan data dalam penelitian ini terdapat pada tabel 1.

Tabel 1. Instrumen Motorik Kasar Anak Usia 5-6 tahun

\begin{tabular}{|c|c|c|c|}
\hline Variabel & Subvariabel & Indikator & Item \\
\hline \multirow{4}{*}{$\begin{array}{l}\text { Kemampuan } \\
\text { Motorik Kasar } \\
\text { Anak Usia 5-6 } \\
\text { Tahun }\end{array}$} & Kelincahan & Berlari zig-zag & $\begin{array}{l}\text { Anak berlari zig-zag mengikuti pola } \\
\text { yang ditandai dengan } 8 \text { buah corong }\end{array}$ \\
\hline & Kecepatan & $\begin{array}{l}\text { Berlari bolak- } \\
\text { balik }\end{array}$ & $\begin{array}{l}\text { Anak berlari bolak balik } \\
\text { memindahkan bola dengan jarak } 3 \\
\text { meter }\end{array}$ \\
\hline & Kekuatan & Melompat & $\begin{array}{l}\text { Anak mampu melompat hulahoop } \\
\text { sebanyak } 4 \text { buah sambil mengubah } \\
\text { posisi gelas plastik }\end{array}$ \\
\hline & Keseimbangan & $\begin{array}{l}\text { Berjalan meniti } \\
\text { dipapan titian }\end{array}$ & $\begin{array}{l}\text { Anak mampu } \quad \text { berjalan } \\
\text { jinjitdipapan titian } \\
\text { meter }\end{array}$ \\
\hline
\end{tabular}

Observasi dilakukan untuk mengetahui perbedaan kemampuan motorik kasar anak sebelum dan sesudah diberikan tindakan atau treatment melalui permainan sirkuit pos geometri. Instrumen penilaian observasi menggunakan kriteria: 1= belum berkembang (BB), $2=$ mulai berkembang $(\mathrm{MB}), 3=$ berkembang sesuai harapan $(\mathrm{BSH}), 4=$ berkembang sangat baik (BSB). Penelitian dikatakan berhasil apabila anak telah menunjukkan peningkatan kemampuan motorik kasar sudah berkembang sesuai harapan.

\section{HASIL DAN PEMBAHASAN}

Setelah mengetahui metodologi dan prosedur penelitian ini, maka ditemukan berbagai hasil dan pembahasan yang berakitan dengan model permainan sirkuit pos geometri pada perkembangan motorik kasar anak usia 5-6 tahun. Pada penelitian ini, peneliti melakukan uji asumsi, uji asumsi yang dilakukan berupa uji normalitas, uji homogenitas, dan uji linearitas. Uji asumsi yang digunakan untuk memverifikasi hipotesis penelitian dan ketika hasil Asym. Sig test mencapai $\mathrm{P}<0,05$ maka hipotesis diterima. Sehingga disimpulkan bahwa model permainan sirkuit pos geometri efektif dapat meningkatkan kemampuan motorik kasar anak usia 5-6 tahun.

\section{Deskripsi Hasil Perkembangan Motorik Kasar Anak}

Tabel 2. Data Hasil Pretest Posttest

\begin{tabular}{ccc}
\hline Hasil & \multicolumn{2}{c}{ Motorik Kasar } \\
& Pretest & Posttest \\
\hline Jumlah Anak (N) & 20 & 20 \\
Nilai Maksimum & 13 & 16 \\
Nilai Minimum & 6 & 10 \\
Skor Rata-rata & 8,35 & 14,45 \\
\hline
\end{tabular}

Dari tabel 2 dapat dilihat skor rata-rata pretest sebesar 8,35 kemudian setelah diberi perlakuan dengan menggunakan permainan sirkuit pos geometri diperoleh rata-rata skor sebesar 14,45. Maka dapat disimpulkan terdapat perubahan sebelum dan sesudah penerapan model permainan sirkuit pos geometri. 
Hasil Rekapan nilai Pre-test dan Post-test

Tabel 3. Nilai Pre-test dan Post-test Anak

\begin{tabular}{cccc}
\hline No. & Kode Anak & \multicolumn{2}{c}{ Penilaian } \\
& & Pre-test & Post-test \\
\hline 1 & A1 & 8 & 14 \\
2 & A2 & 10 & 14 \\
3 & A3 & 8 & 15 \\
4 & A4 & 8 & 13 \\
5 & A5 & 7 & 16 \\
6 & A6 & 10 & 15 \\
7 & A7 & 7 & 13 \\
8 & A8 & 8 & 15 \\
9 & A9 & 9 & 14 \\
10 & A10 & 9 & 13 \\
11 & A11 & 8 & 15 \\
12 & A12 & 9 & 16 \\
13 & A13 & 9 & 14 \\
14 & A14 & 7 & 15 \\
15 & A15 & 6 & 15 \\
16 & A16 & 9 & 13 \\
17 & A17 & 7 & 14 \\
18 & A18 & 9 & 15 \\
19 & A19 & 10 & 16 \\
20 & A20 & 9 & 14 \\
\hline
\end{tabular}

Tabel 4. Nilai Rata-rata Pretest Anak

\begin{tabular}{|c|c|c|c|c|c|}
\hline \multirow[t]{2}{*}{ No. } & \multirow[t]{2}{*}{ Kode Anak } & \multicolumn{4}{|c|}{ Penilaian } \\
\hline & & BB & MB & BSH & BSB \\
\hline 1 & A1 & & $\mathrm{V}$ & & \\
\hline 2 & A2 & & V & & \\
\hline 3 & A3 & & V & & \\
\hline 4 & A4 & & V & & \\
\hline 5 & A5 & & V & & \\
\hline 6 & A6 & & V & & \\
\hline 7 & A7 & & V & & \\
\hline 8 & A8 & & V & & \\
\hline 9 & A9 & & V & & \\
\hline 10 & A10 & & V & & \\
\hline 11 & A11 & & V & & \\
\hline 12 & A12 & & V & & \\
\hline 13 & A13 & & V & & \\
\hline 14 & A14 & & V & & \\
\hline 15 & A15 & & V & & \\
\hline 16 & A16 & & V & & \\
\hline 17 & A17 & & V & & \\
\hline 18 & A18 & & V & & \\
\hline 19 & A19 & & V & & \\
\hline 20 & A20 & & V & & \\
\hline
\end{tabular}

Tabel 5. Nilai Rata-rata Post-test Anak

\begin{tabular}{|c|c|c|c|c|c|}
\hline \multirow[t]{2}{*}{ No. } & \multirow[t]{2}{*}{ Kode Anak } & \multicolumn{4}{|c|}{ Penilaian } \\
\hline & & BB & MB & BSH & BSB \\
\hline 1 & A1 & & 14 & $\mathrm{~V}$ & \\
\hline 2 & A2 & & 14 & V & \\
\hline 3 & A3 & & 15 & V & \\
\hline 4 & A4 & & 13 & V & \\
\hline 5 & A5 & & 16 & & V \\
\hline 6 & A6 & & 15 & V & \\
\hline 7 & A7 & & 13 & V & \\
\hline 8 & A8 & & 15 & V & \\
\hline 9 & A9 & & 14 & V & \\
\hline 10 & A10 & & 13 & V & \\
\hline 11 & A11 & & 15 & V & \\
\hline 12 & A12 & & 16 & & V \\
\hline 13 & A13 & & 14 & V & \\
\hline 14 & A14 & & 15 & V & \\
\hline 15 & A15 & & 15 & V & \\
\hline 16 & A16 & & 13 & V & \\
\hline 17 & A17 & & 14 & V & \\
\hline 18 & A18 & & 15 & $\mathrm{~V}$ & \\
\hline 19 & A19 & & 16 & & V \\
\hline 20 & A20 & & 14 & V & \\
\hline
\end{tabular}

Keterangan: Belum Berkembang (BB), jika nilai hitungan akhir antara 1-5. Mulai Berkembang (MB), jika nilai hitungan akhir antara 6-10. Berkembang Sesuai Harapan (BSH), jika nilai hitungan akhir antara 11-15. Berkembang Sangat Baik (BSB), jika nilai hitungan akhir antara 16-20. 
DOI: 10.31004/obsesi.v6i3.1896

Berdasarkan tabel 4 terlihat bahwa pada pre-test, kemampuan motorik kasar anak memperoleh nilai mulai berkembang $(\mathrm{MB})$, setelah diberikan perlakuan yaitu permainan sirkuit pos geometri pada tabel 5 terlihat bahwa pada post-test, dari 20 orang anak terdapat 3 anak memperoleh nilai Berkembang sesuai harapan (BSB) dan 17 anak berada pada nilai Berkembang Sesuai Harapan (BSH). Dengan demikian dapat dinyatakan bahwa permainan sirkuit pos geometri berpengaruh terhadap motorik kasar anak usia 5-6 tahun di PAUD Mawar.

Penelitian ini menguji hipotesis atau hubungan sehingga peneliti terlebih dahulu melakukan uji hipotesis berupa uji normalitas dan uji homogenitas sebagai syarat dalam penggunaan analisis uji-t. Adapunhasil uji prasyarat sebagai berikut:

\section{Uji Normalitas}

Uji normalitas digunakan untuk mengetahui nilai residual yang diteliti berdistribusi normal atau tidak normal. Pengujian ini menggunakan uji normalitas Kolmogorov-Smirnov.Hasil dari uji normalitas dapat dilihat pada tabel 6 .

Tabel 6. Uji Normalitas

One-Sample Kolmogorov-Smirnov Test

\begin{tabular}{|ll|r|}
\hline & & \multicolumn{2}{|c|}{$\begin{array}{c}\text { Unstandardized } \\
\text { Residual }\end{array}$} \\
\hline N & Mean & 20 \\
Normal Parameters & Std. &, 0000000 \\
& Deviation &, 99865919 \\
Most Extreme & Absolute &, 204 \\
Differences & Positive &, 170 \\
Kolmogorov-Smirnov Z & Negative & -204 \\
Asymp. Sig. (2-tailed) &, 913 \\
\hline
\end{tabular}

a. Test distribution is Normal.

b. Calculated from data.

Untuk pengambilan kesimpulan untuk data berdistribusi normal ialah jika nilai sig. $>$ 0,05, dan sebaliknya untuk data tidak berdistribusi tidak normal ialah nilai sig. < 0,05. Berdasarkan tabel 6 dapat diambil kesimpulan jika nilai sig. 0,375 lebih besar dari 0,05 berarti sesuai dengan asumsi yang telah dijabarkan, maka nilai residual berdistribusi normal.

\section{Uji Homogenitas}

Pengujian ini digunakan untuk meyakinkan ahwa kelompok data memang berasal dari populasi yang memiliki varians yang sama (homogen). Hasil uji homogenitas dapat dilihat pada tabel 7 .

Tabel 7. Uji Homogenitas

Test of Homogeneity of Variances

Motorik Kasar

\begin{tabular}{|r|r|r|r|}
\hline Levene Statistic & \multicolumn{1}{|c|}{ df1 } & \multicolumn{1}{c|}{ df2 } & \multicolumn{1}{|c|}{ Sig. } \\
\hline, 345 & 1 & 38 &, 560 \\
\hline
\end{tabular}

Dasar pengambilan kesimpulan nilai sig. > 0,05 maka distribusi data homogen, apabila jika nilai sig. $<0,05$ maka distribusi data tidak homogen. Berdasarkan tabel diatas dapat di simpulkan bahwa nilai sig. 0,560 lebih besar dari 0,05 sesuai dengan asumsi yang telah dijabarkan, maka kelompok data sampel memiliki varians yang sama (homogen). 


\section{Uji Hipotesis}

Uji hipotesis digunakan guna mengetahui pengaruh perlakuan permainan sirkuit pos geometri terhadap kemampuan motorik kasar anak usia 5-6 tahun, maka perlu dilihat perbedaan atau hubungan data pretest dan posttest dengan menggunakan uji paired sample T-test. Hasil uji Hipotesis dapat dilihat pada tabel 8.

Tabel 8. Uji Homogenitas

Paired Samples Test

\begin{tabular}{|c|c|c|c|c|c|c|c|c|c|}
\hline & \multicolumn{5}{|c|}{ Paired Differences } & \multirow[t]{3}{*}{$\mathrm{t}$} & \multirow[t]{3}{*}{$\mathrm{df}$} & \multirow{3}{*}{$\begin{array}{l}\text { Sig. (2- } \\
\text { tailed) }\end{array}$} \\
\hline & & \multirow[t]{2}{*}{ Mean } & \multirow[t]{2}{*}{$\begin{array}{c}\text { Std. } \\
\text { Deviation }\end{array}$} & \multirow[t]{2}{*}{$\begin{array}{l}\text { Std. } \\
\text { Error } \\
\text { Mean }\end{array}$} & \multicolumn{2}{|c|}{$\begin{array}{l}95 \% \text { Confidence } \\
\text { Interval of the } \\
\text { Difference } \\
\end{array}$} & & & \\
\hline & & & & & Lower & Upper & & & \\
\hline Pair 1 & $\begin{array}{l}\text { Pretest - } \\
\text { Posttest }\end{array}$ & $-6,100$ & 1,518 & 340 & $-6,811$ & $-5,389$ & $-17,967$ & 19 & , 000 \\
\hline
\end{tabular}

Dasar pengambilan keputusan jika nilai sig. $<0,05$ maka adanya perbedaan yang signifikan antara data pretest dan data posttest. Sedangkan jika nilai sig. $>0,05$ makatidak adanya perbedaan yang signifikan antara pretest dan posttest. Berdasarkan tabel 8 diatas dapat dilihat nilai sign. (2-tailed) sebesar 0,000 yang artinya sig. < 0,05, maka dapat disimpulkan bahwa terdapat perbedaan yang signifikan antara hasil pretest dan posttest. Ini menunjukkan adanya pengaruh permainan sirkuit pos geometri terhadap kemampuan motorik kasar anak usia 5-6 tahun dan memperoleh nilai berkembang sesuai harapan (BSH).Berdasarkan hasil observasi dan test yang dilakukan bahwa 20 orang anak yang menjadi subjek penelitian, $15 \%$ anak masuk dalam kategori berkembang sangat baik (BSB), $85 \%$ anak masuk dalam kategori berkembang sesuai harapan (BSH).

\section{Pembahasan}

Pelaksanaan pada penelitian ini menggunakan permainan sirkuit pos geometri yang dirancang untuk mengembangkan motorik kasar anak usia 5-6 tahun dengan tahapan dan karakteristik anak usia 5-6 tahun. Menurut Burton \& Miller (Eriani \& Dimyati, 2019) untuk membangun keterampilan motorik, anak harus mampu mempersepsikan sesuatu di lingkungannya yang memotivasinya untuk melakukan sesuatu untuk bergerak. Motorik kasar merupakan bagian yang penting dari proses pertumbuhan yang nantinya berperan dalam kemampuan seseorang menjalani kehidupannya yang aktif secara fisik. Keterampilan motorik kasar memberikan dasar untuk perolehan keterampilan kompleks yang dugunakan dalam melakukan aktivitas yang berkaitan dengan kebugaran fisik, kesehatan, dan olahraga (Bardid et al., 2016; Viegas et al., 2021). Untuk itu,guru diharapkan bisa mengembangkan model atau metode pembelajaran yang berbasis permainan yang dapat meningkatkan kemampuan motorik terlebih motorik kasar anak sehingga anak terlibat secara bersamaan dengan otak dan tubuh anak dalam belajar.Kamal \& Chowdhury(2019) bermain dapat menawarkan pendekatan pembelajaran yang efektif untuk mencapai prioritas dalam pemilihan metode pembelajaran untuk anak, sehingga dalam pengimplementasiannya bermain dijadikan sebagai sarana pembelajaran bagi anak. Penelitian Pradaya et al. (Reswari, 2021) yang mengemukakan bahwa kemampuan motorik kasar dapat ditingkatkan dengan permainan olahraga, salah satunya ialah permainan sirkuit pos geometri.

Permainan sirkuit pos geometri dapat meningkatkan indikator motorik kasar seperti kekuatan, keseimbangan, kelincahan dan kecepatan. Tidak hanya meningkatkan motorik kasar anak tetapi juga dapat membantu anak dalam pengenalan bentuk geometri(kognitif), kemandirian saat bermain, dan mengajarkan anak untuk bersabar ketikan menunggu giliran bermain. Anak menunjukkan atusiasme yang tinggi ketika anak sedang bermain. Anak mendapatkan pengalaman baru dan menyenangkan. Hasil penelitian ini sejalan dengan 
penelitian sebelumnya menunjukkan bahwa permainan sirkuit bola keranjang berhasil meningkatkan kemampuan motorik kasar anak usia (Selman et al., 2021). Penelitian Komarisa \& Ardianingsih(2020) menunjukkan bahwa permainan sirkuit sebagai strategi untuk membantu meningkatkan motorik kasar anak autisme. Melalui observasi yang telah dilakukannya, siswa menjadi aktif, lebih tertarik dalam kegiatan belajar mengajar, dan tidak bosan selama proses pembelajaran. Selain itu, penelitian Riswandi (2021) juga mendapatkan hasil bahwa permainan sirkuit efektif dan layak digunakan guru dalam peningkatan motorik kasar anak usia 5-6 tahun. Melalui permainan ini anak dapat menyalurkan energinya melalui gerakan, sehingga anak memperoleh kepuasan dan kesenangan dalam bermain.

\section{SIMPULAN}

Keterampilan motorik kasar anak usia 5-6 tahun di PAUD Mawar Kecamatan Baktiraja mampu ditingkatkan melalui permainan sirkuit pos geometri, dengan kata lain penggunaan permainan sirkuit pos geometri berpengaruh terhadap motorik kasar anak usia 5-6 tahun. Hal ini dikarenakan permainan sirkuit pos geometri mengandung unsuraktivitas fisik yang dapat meningkatkan kemampuan motorik anak khususnya motorik kasar anak. Permainan sirkuit pos geometri tidak hanya meningkatkan motorik kasar anak tetapi juga membantu anak dalam pengenalan bentuk geometri (kognitif) dan juga kemandirian anak saat bermain. Selain itu, permainan ini juga mengajarkan anak untuk sabar ketika menunggu giliran untuk bermain.

\section{UCAPAN TERIMAKASIH}

Terimakasih kepada Anak-anak Usia 5-6 Tahun dan Guru PAUD Mawar Desa Simamora yang sudah bersedia menjadi membantu dan bekerjasama dalam penelitian ini.Terimakasih juga kepada Bapak Dimyatiselaku dosen pembimbing penulisan artikel ini. Tidak lupa terimakasih juga kepada kedua orangtua yang senantiasa mendukung materil dan moril. Terakhir terimakasih kepada Tim editor Jurnal Obsesi sehinga artikel ini dapat memungkinkan untu diterbitkan.

\section{DAFTAR PUSTAKA}

Bardid, F., Huyben, F., Lenoir, M., Seghers, J., Martelaer, K. De, Goodway, J. D., \& Deconinck, F. J. A. (2016). Assessing fundamental motor skills in Belgian children aged 3-8 years highlights differences to US reference sample. Acta Paediatrica, e281-e290. https://doi.org/10.1111/apa.13380

Barnett, L. M., Hnatiuk, J. A., Salmon, J., \& Hesketh, K. D. (2019). Modifiable factors which predict children's gross motor competence: a prospective cohort study. International Journal of Behavioral Nutrition and Physical Activity, 16(129), 1-11. https:// doi.org/10.1186/s12966-019-0888-0

Botha, S., \& Africa, E. K. (2020). The Effect of a Perceptual Motor Intervention on the Relationship Between Motor Proficiency and Letter Knowledge. Early Childhood Education Journal, 0123456789. https://doi.org/10.1007/s10643-020-01034-8

Charles, S., Tua, P., \& Yuwono, N. (2021). Pendidikan Dini Prinsip Edukasi Kesehatan Gizi Seimbang melalui metode Kids Play and Care. To Maega: Jurnal Pengabdian Masyarakat, 4(2), 179-186. https://doi.org/10.35914/tomaega.v4i2.743

Eriani, E., \& Dimyati. (2019). Fantasy Gymnastic as an Active and Imaginative Learning Model to Children 's Gross Motor. International Conference on Special and Inclusive Education (ICSIE 2018), 296(Icsie 2018), 408-411. https://doi.org/10.2991/icsie18.2019 .76

Fadillah, M. (2012). Desain Pembelajaran PAUD: Tinjauan Teoritik. Ar-Ruzz Media.

Hasdianah, H. R., Siyoto, S., \& Yuly, P. (2014). Gizi, Pemanfaatan Gizi, Diet Dan Obesitas. Nuha Medika. 
In: Administration for Children and Families, E. (2015). Head Start Early Learning Outcomes Framework: Ages Birth to Five. U.S. Dapartement of Health and Human Services.

Kamal, M. M., \& Chowdhury, M. S. R. (2019). The Role of Head Teachers in Ensuring Joyful Learning Environment in Goverment Primary School (GPS) of Banglasdesh. IJARIIE, 5(4), 2395-4396.

Komarisa, P., \& Ardianingsih, F. (2020). Permainan Sirkuit sebagai Strategi untuk Meningkatkan Keterampilan Motorik Kasar Anak dengan Autisme. Jurnal Pendidikan Khusus, 1-9. https://doi.org/10.31004/obsesi.v6i1.1166

Kurniawan, H., Mawarny, \& Laely, T. A. (2020). Bermain dan Permainan Anak Usia Dini (A. Asmara (ed.)). PT. Remaja Rosdakarya.

Lopes, L., Santos, R., Pereira, B., \& Lopes, V. P. (2013). Associations between gross Motor Coordination and Academic Achievement in elementary school children. Human Movement Science, 32, 9-20. https:/ / doi.org/10.1016/i.humov.2012.05.005

Mahmud, B. (2018). Urgensi Stimulasi Kemampuan Motorik Kasar Pada Anak Usia Dini. $\begin{array}{llll}\text { Didaktika, Jurnal } \quad \text { Kependidikan, } & \text { 12(1), }\end{array}$ https://doi.org/10.30863/didaktika.v12i1.177

Meylia, K. N., Siswati, T., Paramashanti, B. A., \& Hati, F. S. (2020). Fine motor, gross motor, and social independence skills among stunted and non-stunted children. Early Child Development and Care, 0(0), 1-8. https:/ / doi.org/10.1080/03004430.2020.1739028

Montessori, M. (2019). Montessori Mendidik Anak Sejak Lahir: Pendidikan Anak-anak di Rumah dari Usia 0-3 Tahun. Pustaka Belajar.

Morrison, K. M., Cairney, J., Eisenmann, J., Pfeiffer, K., \& Gould, D. (2018). Associations of Body Mass Index, Motor Performance, and Perceived Athletic Competence with Physical Activity in Normal Weight and Overweight Children. Journal of Obesity. https:// doi.org/10.1155/2018/3598321

Mutiah, D. (2012). Psikologi Bermain Anak Usia Dini. Kencana Perdana Media Group.

Nasution, S. T., \& Sutapa, P. (2021). Strategi Guru dalam Menstimulasi Keterampilan Motorik AUD Pada Era Pandemi Covid 19. Jurnal Obsesi: Jurnal Pendidikan Anak Usia Dini, 5(2), 1313-1324. https://doi.org/10.31004/obsesi.v5i2.849

Ramdani, L. A., \& Azizah, N. (2020). Permainan Outbound untuk Perkembangan Motorik Kasar Anak Usia Dini. Jurnal Obsesi: Jurnal Pendidikan Anak Usia Dini, 4(1), 482-490. https:// doi.org/10.31004/obsesi.v4i1.407

Republik Indonesia, K. K. (n.d.). Hasil Utama RISKESDAS 2018.

Reswari, A. (2021). Efektivitas Permainan Bola Basket Modifikasi terhadap Kemampuan Motorik Kasar Anak Usia 5- 6 Tahun. Jurnal Obsesi: Jurnal Pendidikan Anak Usia Dini, 6(1), 17-29. https://doi.org/10.31004/obsesi.v6i1.1182

Riswandi, F. N. (2021). Peningkatan Kemampuan Motorik Kasar Melalui Pengembangan Model Sirkuit Anak Usia 5-6 Tahun. Jurnall PG-PAUD Trunojoyo: Jurnal Pendidikandan Pembelajaran Anak Usia Dini, 8(April). https:// doi.org/10.21107/pgpaudtrunojoyo.v8i1.10233

Selman, H., Said, H., Sasnita, U., \& Indah, T. (2021). Sirkuit Bola Keranjang: Permainan untuk Meningkatkan Kemampuan Motorik Kasar Anak Usia Dini. Jurnal Obsesi: Jurnal Pendidikan Anak Usia Dini, 5(2), 2025-2036. https:// doi.org/10.31004/obsesi.v5i2.1077

Shirin, A. (2020). Does Play Help to Learn Vocabulary? A Case Study on Primary School Teacher's Attitude of Dhaka City in Bangladesh. Indonesian Journal of Early Childhood, 9(1), 53-61. https://doi.org/10.15294/ijeces.v9i1.38891

Sugiyono. (2019). Metode Penelitian Kuantitatif, Kualitatif dan R\&D (Kedua). Penerbit Alfabet.

Suharjana. (2014). Kebugaran Jasmani. Jogja Global Media.

Sulistyaningtyas, Edwin, R., \& Fauziah, P. Y. (2019). Pengembangan buku panduan permainan tradisional untuk meningkatkan kemampuan motorik kasar anak usia 5-6 tahun. JPPM 
DOI: 10.31004/obsesi.v6i3.1896

(Jurnal Pendidikan Dan Pemberdayaan Masyarakat), 6(1), 50-58. https://doi.org/10.21831/jppm.v6i1.23477

Susanti, R. azharona. (2014). Improvement of Physical Fitness Through Cheerful Colours Circuit Game. Jurnal Pendidikan Anak Usia Dini, 8(2), 347-258.

Teresa, M., Henrique, S., Hervaldo, A., Ré, N., Santos, I., Oliveira, D., Machado, B., Sousa, M. De, Cappato, R., Araújo, D., \& Stodden, D. (2016). Motor competence and health related physical fitness in youth: A systematic review. Journal of Science and Medicine in Sport, 19(2), 123-129. https://doi.org/10.1016/j.jsams.2014.12.004

Veldman, S. L. C., Jones, R. A., Chandler, P., Robinson, L. E., \& Okely, A. D. (2019). Prevalence and Risk Factors of Gross Motor Delay in Preschoolers. Journal of Paediatrics and Child Health, 1-6. https://doi.org/10.1111/jpc.14684

Viegas, Â. A., Mendonça, V. A., Pontes, J. N., Luzia, R., Morais, D. S., Fernandes, A. C., Ferreira, F. D. O., Henrique, P., Figueiredo, S., Leite, R., Cristina, A., Camargos, R., Rodrigues, A. C., Luzia, R., Morais, D. S., Fernandes, A. C., Oliveira, F. De, Henrique, P., Figueiredo, S., ... Lacerda, R. (2021). Associations of physical activity and cognitive function with gross motor skills in preschoolers: Cross-sectional study. Journal of Motor Behavior, 0(0), 1-16. https://doi.org/10.1080/00222895.2021.1897508

Yus, A. (2013). Bermain sebagai Kebutuhan dan Strategi Pengembangan Diri Anak. Jurnal Ilmiah VISI P2TK PAUDNI, 8(2), 153-158. https:// doi.org/10.21009/JIV.0802.9 